\title{
ASPECTS OF MEDIATION IN ROMANIA
}

\section{G. Bunea}

\section{Gheorghe Bunea}

Faculty of Law, the Law Department

"Bogdan Voda" University of Cluj-Napoca, Romania

*Correspondence: Gheorghe Bunea, "Bogdan Voda" University, 26A Grigore Alexandrescu, Cluj-Napoca, Romania

E-mail: buneagheorghe@yahoo.com

\begin{abstract}
An important concern for the European Council in the past 15 years was to find ways for settling some divergences appearing in European Union countries. For this purpose, a number of recommendations were adopted for their settlement by mediation. We have tried below a presentation thereof as well as of some aspects related to mediation in our country.
\end{abstract}

Keywords: mediation, conflict, negotiation, law, crime, civil case

\section{Introduction}

Mediation it is a very current legal instrument intended for conflict resolution, which starts from the principle of offsetting the parties' interests, based on their free will, durable and perceived as very advantageous. This is the only alternative whereby judges are benefited in the context of the globalization phenomenon, to get rid of the many cases they should settle.

Mediation can settle in a balanced and concessive manner the interests of both the citizens and the State in the same time, an activity whereby conflict situations are settled amicably, over a much shorter period of time and with greatly reduced costs.

Although it approaches issues related to relationship and communication as well, mediation as defined by Christopher Moore (1996) places the most attention on the negotiation between the parties in order to make the best decision regarding the problem they face, mutually accepted by them ${ }^{1}$. The choice of approach to mediation supports also situations in which negotiation may appear at the end of a case or relationship, and not necessarily at the beginning thereof or to strengthen the relationship or to settle it favorably for the parties.

The concern for establishing criteria for balancing the gains and losses must exceed for the parties involved the barrier of their own interests, having to the fore their common interest.

The Council of Europe has adopted several Recommendations relating to mediation, establishing principles and directions for action addressed to the Member States, namely Recommendation no. 98 (1) on family mediation, Recommendation no. 99 (19) concerning mediation in penal matters, Recommendation no. 2001 (9) on the alternatives to litigation between administrative authorities and private persons and Recommendation no. 2002 (10) with regard to mediation in civil matters. Furthermore, in 2007, the Council of Europe has adopted three guidelines in criminal, civil and administrative matters, and later, in 2002, the 
European Commission has adopted the Green Paper, which stipulates alternatives to settle disputes in civil and commercial matters.

The emergence of these European imperatives meant to settle the many conflicts by means of mediation led to the adoption in our country of the Law no. 192/2006 on mediation and organization of the mediator profession.

The European Union has adopted one more directive with direct effect on mediation and implicitly on the regulatory documents related to this area, namely Directive no. 2008/52/EC of the European Parliament on aspects of mediation in civil and commercial matters, which allowed European States to apply it also in their internal procedures.

\section{Mediation in criminal cases}

Mediation as an alternative method of dispute settlement offers the possibility of placing a third party in the conflict between the parties, which is neutral and unbiased and which presents the legal means by which one can identify a solution beneficial to all parties involved, all the more so in criminal conflict mediation. The mediator's role is to bring in the center of the negotiations the parties' demands and claims, to encourage the outlining of an agreement between those involved.

The legal framework is provided by the Law no. 192/2006 on mediation and organization of the mediator profession and by the Law no. 202/2010 modifying the Criminal Procedure Code, which, in art. 10 paragraph 1 letter (h) has the following wording: "prior complaint was withdrawn or parties reconciled or an agreement for mediation according to the law was entered into, in the case of offences for which the withdrawal of a complaint or reconciliation of parties precludes criminal liability".

This provision prevents the implementation of criminal action or the exercise of criminal action or, if they have been made after the agreement, they shall cease. The conclusion of a mediation agreement can be done only for the crimes for which the withdrawal of the complaint or the reconciliation of the parties precludes criminal liability, crimes investigated at the prior complaint of the injured party. In practice, the most common mediation cases are found in the crimes of violence, art. 180 of the Criminal Code, personal injury, art. 181 of the Criminal Code, personal injuries through negligence article 184 of the Criminal Code, rape, article 197 of the Criminal Code, destruction, art. 217 of the Criminal Code and family abandonment referred to in art. 305 of the Criminal Code.

\section{The conclusion of the mediation agreement}

According to Law no. 202/2010, art. 56 paragraph (1), mediation procedure ends "by the conclusion of an agreement between the parties as a result of conflict settlement". It is worth mentioning that art. 56 paragraph (1) of Law no. 192/2006 shows that when the parties are in conflict and reach an understanding, one can draw up a written agreement containing all the terms undertaken, which has the value of a private deed. This agreement is drawn up by the mediator, except for the situations when the parties and the mediator agree on its drawing up. ${ }^{2}$

The conclusion of the mediation agreement is performed following a mediation procedure that goes through several stages. In accordance with Law no. 192/2006, these stages are: the procedure prior to the conclusion of the mediation agreement, mediation performance and the termination of the mediation procedure, which is made "by the conclusion of an agreement between the parties, following conflict resolution" [art. 56 paragraph (1) letter (b)], "by the finding by the mediator of mediation failure" [art. 56 paragraph (1) letter (b-)], "by submitting the mediation agreement by one of the parties"

\footnotetext{
${ }^{2}$ Dumitru-Virgil Diaconu, Mediation in criminal causes, Ed. C.H. Beck, Bucharest 2012, pag. 5
} 


\section{G. Bunea}

[art. 56 paragraph (1) letter (c)] or "the unilateral termination of the mediation agreement [art. 60 paragraph (1) and (2)].

\section{Mediation concerning the civil side of the case}

Mediation on the civil side of the case is regulated by the Criminal Procedure Code, as amended by Law no. 202/2002, art. 16 being entitled "Transaction, mediation and recognition of civil claims".

Thus, paragraph (1) states that "the defendant, during the entire criminal trial, both the civil party and the party liable in civil terms, may conclude a transaction or an agreement for mediation, according to the law". In paragraph (2) "the defendant, with the consent of the party liable in civil terms, may recognize, in whole or in part, the claims of the civil party".

By Law no. 202/2010, the legislator introduced the procedural institution of mediation, not only on the criminal side, but also on the civil side. With regard to mediation, three ways of settling the civil side in a criminal case were introduced, i.e. mediation, transaction and the total or partial recognition of civil claims.

The new institutions of mediation, transaction and recognition introduced by Law no. 202/2010 in the current Criminal Procedure Code are applicable to the civil side in criminal proceedings, which is completed with rules relating to mediation in the event of a civil dispute pending before the courts.

It should be also stated that mediation, transaction and total or partial recognition in connection with the defendant as covered by the provisions of art. 16 of the Criminal Procedure Code are part of Section II entitled Civil Action, governed by the rules of civil procedure. ${ }^{4}$

\section{Mediation from the perspective of the New Criminal Procedure Code}

To determine the parties or participants to resort to mediation, the New Criminal Procedure Code stipulates the rights of the injured party (art. 81), of the defendant (art. 83), of the civil party [art. 85 paragraph (1)] and of the party liable in civil terms [art. 81 paragraph (1)] to turn to a mediator.

There is a new regulation designed to ensure the complete procedural framework for the compulsory recommendation of mediation not to be only formal, but also effective. That is why the New Criminal Procedure Code provides for the suspension of the criminal case for mediation, both at the stage of proceedings or prosecution, correlating the text of the special law no. 192/2006 with the provisions of the New Criminal Procedure Code.

Regarding the settlement of the civil side of the case, it takes place with the settlement of the criminal side of the case, the Court ruling in the same judgment upon the civil action as well (art. 397), comprising the content of the operative part and the decision made with respect to the settlement of the civil action, which can also be settled by mediation.

\section{Mediation of cross-border conflicts}

Since the 1980s, the continental approach to ADR methods has increased in intensity from Recommendations of the Committee of Ministers concerning the access to justice (1981) or decreasing the burden on the courts (1986), at the level of the Council of Europe - to the most important document of the European Union concerning the mediation: Directive 2008/52/EC. It is noteworthy that the trend goes from simple recommendations to unification at European level, through Directives that, according to their programmatic value, set the

\footnotetext{
${ }^{3}$ M. Udroiu, Procedura penală, Part generală, Part speciala, Ed. C.H. Beck, Bucharest, 2010, p. 38

${ }^{4}$ Dumitru-Virgil Diaconu, Mediation in criminal causes, Ed. C.H. Beck, Bucharest 2012, pag. 8.
} 
goals to be achieved by the Member States, leaving the choice of means to the discretion of national authorities.

In Romania, the mediation and the mediator profession were regulated by the adoption of Law no. 192/2006, presuming that the mediation constitutes one of the major themes of the justice reform strategy and is a priority in the Plan of action for the implementation of the Strategy for the reform of the judiciary 2005-2007, aiming to reduce the activity volume of the courts through the adoption of the law.

Mediation is regarded as an elaborated process in which the parties in conflict have the opportunity to express their wishes, needs, aspirations, expectations and interests, while helping the individual and group reflection, in order to make the most satisfactory decision for themselves.

Directive 2008/52/EC identifies the mediation in cross-border disputes as a distinct field of mediation application. In this respect, the directive brings to the fore the need for differentiation between the general aspects that govern the work of mediators in any event subject to mediation, and the aspects specific to mediation in cross-border litigation. Every situation subject to mediation is different, has its own peculiarities and, as such, requires a permanent adaptation of the mediator, who must demonstrate great flexibility and constant adaptability.

Mediation used in relation to judicial proceedings is primarily oriented towards the mutually agreed formulation by the parties in the conflict of an agreement on the issues that are the subject of the dispute, thus providing an out-of-court alternative, faster and less expensive for them. Statistics at European level in commercial matters indicates that at the level of the 26 Member States the Directive no. 2008/52/EC is applicable to, the duration of a trial is, on average, of 505 calendar days (Belgium), with a maximum of 1,290 calendar days (Slovenia). The statistical costs associated with these trials represent $16.6 \%$ (Belgium), on average, at European level, going up to $33.0 \%$ (Czech Republic) of the amount to be recovered in court. Estimated costs include legal costs (legal fees, experts, etc.), costs for attorneys' fees and expenses incurred for the enforcement of the judgment.

For example, in Belgium the average duration of a trial in court is 505 calendar days and legal costs amount on average to $16.6 \%$ of the amount to be recovered that is the subject of the trial, while in Italy the average duration of a trial is 1,210 calendar days, and legal costs amount on average to $29.9 \%$ of the amount to be recovered in court. Using mediation, parties need on average 45 days in Belgium and 47 days in Italy in order to settle the dispute, and the costs incurred as a result of mediation in these countries amount only to $43.75 \%$ of the costs of a trial in Belgium and only $27.78 \%$ of the costs of a trial in Italy.

\section{Conclusions}

It is obvious that mediation in the field of cross-border disputes pose a high element of complexity due to different laws incidental in the case and due to different national jurisdictions, requiring specialized mediators and a clear framework legislation in crossborder mediation at European level.

It is obvious that the concept of cross-border mediation does not refer exclusively to the disputes mediated in the Member States of the European Union; cross-border mediation refers to the conflicts subject to this ADR method where the parties come from different States, without territorial restriction. Thus, we believe that cross-border mediation in the meaning of the European regulations (in particular, Directive 2008/52/EC of the European Parliament and of the Council of May $21^{\text {st }}, 2008$ on certain aspects of mediation in civil and commercial matters) must not be confused with cross-border mediation defined in universal acceptance. We start from the premise that the directive on mediation in civil and commercial 


\section{G. Bunea}

matters is just a first step in cross-border mediation and by no means a finalized framework legislation that can no longer be improved.

\section{Bibliography:}

Dumitru-Virgil Diaconu, Mediation in criminal cases, With references to the New Criminal Procedure Code, C.H. Beck Publishing House, Bucharest 2012;

M. Udroiu, Procedura penală, Partea Generala, Partea Speciala, Ed. C.H. Beck, Bucharest, 2010, p. 38

Commission Regulation (EC) no. 805/2004 of the European Parliament and of the Council of April 21 ${ }^{\text {st }}, 2004$ creating a European enforcement order for uncontested claims published in the Official Journal of the European Union

http://eurlex.europa.eu/LexUriServ/LexUriServ.do?uri=DD:19:07:32004R0805:RO:PDF;

Green Paper on ADR, 2002

http://eurlex.europa.eu/LexUriServ/site/en/com/2002/com2002_0196en01.pdf;

Council Regulation (EC) no. 44/2001 of December 22nd, 2000 („Brussels I” Regulation) on jurisdiction, recognition and enforcement of judgments in civil and commercial matters published in the Official Journal of the European Union http://eurlex.europa.eu/LexUriServ/LexUriServ.do?uri=DD:19:03:32001R0044:RO:PDF;

The European Justice Portal, www.E-Justice.eu;

http://www.just.ro/LinkClick.aspx?fileticket=OAnizjkbkvo\%3D\&tabid=2563;

Proposal for a regulation of the European Parliament and of the Council on online dispute resolution for consumer disputes (Regulation on OCDR)

http://ec.europa.eu/consumers/redress_cons/docs/directive_adr_ro.pdf; 